\title{
Authenticity of Language Practices in Virtual Learning Sites
}

\author{
Jonathan R. White
}

\section{Introduction}

English has become an international language and is one of the primary means for communication between individuals from different cultural backgrounds. However, people still have mixed attitudes about its status. Some see it as positive that there is a single lingua franca for international communication, while others see the specific choice of English as furthering colonialism and oppression (cf. for example Phillipson, 2013).

In relation to language practices in education, there is a continuing debate on authenticity. What is the most authentic language to learn and teach? In the context of English internationally, this often boils down to the choice between British and American English, especially given the over-abundance of teaching materials focusing on these varieties. However, much research focuses on a more pluralistic view of norms in English, such as the research by proponents of the World Englishes and English as a lingua franca views, for example. Also, net-based learning

\footnotetext{
J. R. White $(\bowtie)$

Department of English, Dalarna University, Falun, Sweden e-mail: jwh@du.se 
environments have been argued to afford for more interaction especially among minorities and those less willing to interact face-to-face. It is argued in this chapter that another affordance of virtual learning sites is that there is a corresponding freer attitude towards norms which can be created through interaction between language users, and there is not the same focus on static, mostly written, norms from Inner Circle countries. The term virtual learning sites is used in this chapter to refer to purely net-based learning sites. Contexts where campus students use online learning management systems like Blackboard or Fronter are not included. The learning, and especially the interaction, needs to take place purely through net-based means.

Research on norms often approaches the issue through attitude research, but I have used a mixed-method approach to compare students' reported attitudes with actual language practices. This mixed method is productive since we can thereby see any discrepancies between the two. Since attitudes to English are so diverse, my intention is to look at the situation within Europe where there may not be the same associations between English and colonialism as there are in an African or Asian context. Results will be presented from a survey of attitudes to English varieties among university students on net-based language courses in Sweden. This is complemented by data coming from textchats produced by these students in a net-based education context. Before presenting the survey and its results, some background on the status of English in the world and in Europe will first be discussed.

\section{Background}

\section{Authenticity in Language Pedagogy}

The debate on authenticity in relation to language learning has raged over many decades, and many different aspects have been taken up. BuendgensKosten (2013) refers to cultural, linguistic or functional authenticity in language teaching, and my focus lies on the first two. Cultural authenticity stems from materials and norms which have their origins within the 
target culture, while linguistic authenticity means that a text is seen as "natural", which basically means a text which a native speaker might produce. We can see that these definitions encode conservative views that the Inner Circle native varieties have the highest status.

However, as Pennycook (2007) has argued, there is a global spread now to authenticity in English language teaching, and local norms are seen as more and more relevant for learners in specific cultural contexts. For example, Alsagoff (2014) notes that, in Singapore, a local identity as speakers of Singapore English (Singlish) takes precedence over their identity as global English learners. Erling (2007), in her survey of German learners, reports that they did not want to learn native speaker norms in English as that would be a betrayal of their selves as native speakers of German. These views can be linked to the theory of L2 self (Dörnyei \& Ushioda, 2009), in that these learners are positioning themselves with respect to norms in the language they are learning. They can choose to assert their identity as non-native speakers of English, as evidenced in the Erling study, or as speakers of non-Inner Circle varieties, as seen in Alsagoff's work.

When seen as an identity issue, Creese, Blackledge, and Takhi (2014) describe authenticity as being negotiated for each specific discourse situation; so maybe in one context, it is native speakers who are authentic, whereas in another, it is non-native speakers. In a similar vein, Hung and Chen (2007) argue for a distinction between context authenticity, where language is authentic in a particular environment, and for process authenticity, which refers to the process of identity formation where authenticity is a more fluid, negotiated object. Lowe and Pinner (2016, p. 34) also describe authenticity as being created through interaction and interpretation, and Pinner $(2014,2016)$ sees it as a continuum, where there are no absolute values.

Li (2010) has noted that the Internet is leading to changes in perceptions of norms in English, in that standard written norms are not seen as relevant in such contexts (cf. also Stockwell, 2013), which is why students taking net-based classes were the focus of the survey reported herein. Since Crystal (2001), it has become commonplace to write about a netspeak, a register of English specific to net-based communication with its own norms of linguistic practice. These norms include markers of 
informality such as the widespread use of contracted forms and elliptical structures, and a move away from standard written language spelling conventions through processes like clipping and homophone respelling (cf. Werry, 1996; White, 2015, 2017, 2018). Netspeak can, in fact, be seen as authentic in a net-based environment, although whether this is true for a virtual learning site is a question to be taken up later.

We have, therefore, a complex view of authenticity. The traditional perspective that authentic means native speaker written norms and language use seems to be changing in favour of a more fluid, contextually based view where the local context is most important for deciding authenticity. Also, informal language norms can be authentic in particular discourse contexts, such as net-based communication. Research on the status of local varieties of English will be taken up in the next sub-section.

\section{English as a Lingua Franca and World Englishes}

In research, there are a number of main perspectives on the targets for learners of English that go against the native-only focus with respect to norms. One is the English as a lingua franca (ELF) view of researchers like Seidlhofer (2004) and Jenkins (2002, 2007); another is the World Englishes (WE) view of Kachru (1985); and a third is English as an International Language of McKay (2002), for example, which to some extent combines the former two approaches.

Kachru's (1985) classic work identified three categories of Englishes: the native speaker Inner Circle; the Outer Circle, where English is used as an official language; and finally the Expanding Circle, where English is a second or foreign language without official status. In general, we can say that the World Englishes paradigm has been instrumental in promoting the view that non-native varieties of English are legitimate targets for second-language learners.

Modiano (2009) describes the difference between ELF and EIL as that, in the latter, the focus is on the use of English in multicultural communication forums with a mix of both native and non-native speakers. The aim is the identification of core linguistic features for communication. ELF focuses, on the other hand, on the pragmatics of communication 
between non-native speakers only. As Modiano (2003) puts it, ELF is based on an ability for non-native speakers to adapt to different communicative situations with other non-native speakers. Jenkins $(2002,2007)$ has proposed a core of pronunciation features for English pronunciation syllabi based on her work on intelligibility in ELF discourse; and work in pragmatics and syntax has tried to identify similar features that could form the basis of ELF pedagogical materials (cf. Seidlhofer, Breiteneder, \& Pitzl, 2006).

Saraceni $(2008$, p. 25) has noted three different uses of the term ELF. One is that it is functional, that is, it refers to the English used in interactions between second-language users who do not share a common first language; second, it can refer to local varieties of English emerging in the Expanding Circle; and finally, it can refer to a specific variety emerging from interactions between second language users (e.g. a Euro-English for interactions among speakers of European language). Saraceni himself advocates a functional perspective as opposed to ELF as an emergent variety (a view also held by House, 2014). Cogo (2008), in reply to Saraceni, argues for both a functional and a formal definition of ELF. Specific forms are negotiated and accommodated in interactions between second-language users of English, and therefore, function and form follow from one another in a continuous circle of linguistic change, possibly leading to the development of a stable variety.

However, the debate on whether there is an accepted ELF variety is inconclusive. As already noted, Jenkins (2002) has presented a core of pronunciation features for ELF which can form the basis of a pronunciation curriculum. Regarding grammatical norms, Mollin (2006, 2007) studied her own corpus of Euro-English and concluded that there were few specifically non-native features that united speakers; rather, there were mostly standard native features and some individual variations. For example, one of the features Seidlhofer (2004) suggested as a potential feature of a Euro-English variety is the loss of the $-s$ agreement marker with third person singular subjects. Out of 2700 instances of such subjects in Mollin's corpus, the $-s$ marker was only missing in 16 cases. Contrary to Mollin's work, Seidlhofer et al. (2006) argue on the basis of case studies of the use of $-s$ agreement and pragmatic miscommunication in ELF discourse that there is evidence of Euro-English norms emerging. 
Regarding the $-s$ agreement marker specifically, zero marking was found in 29 out of 141 possible contexts (20.57\%, cf. Seidlhofer et al., 2006, p. 14). A total of 22 out of 41 speakers did not follow standard agreement marking at some point. As they note, there is evidence of the transfer of L1 features into English, especially lexical. It is unclear, though, whether this is becoming a standardised norm in an ELF variety.

As well as distinctive grammatical features, Mollin (2007, p. 173) notes a number of different criteria that can be used to identify if a variety has been formed (cf. also Prodromou, 2007). They include official recognition, and the use of the "variety" in education, the media and administration. While it is certainly the case that English as a whole is extensively used in administration and education in the European Union, it is doubtful on the basis of Mollin's analysis that ELF and Euro-English have achieved the kind of official recognition that would suggest they have the status of new varieties. As a result, she concluded that there was no strong evidence for ELF as a new variety of English. Rather, it should be classified instead as a functional variety-being used for communication with and among second-language users of English. Of course, her work is more than ten years old as of the time of writing, and this status may have changed over the years.

The crucial point from WE, ELF and EIL research is that non-native varieties of English are as good a target for learners as native ones. However, attitudes among learners and teachers very often lag behind the research-based debate, as noted by Groom (2012). Finally in this background, attitudes to English, specifically in Europe, are discussed.

\section{English in Europe}

In Europe, just as in Asia and Africa, issues to do with proficiency and hegemony are very common when discussing the role of English. Hilgendorf (2007) discusses the linguistic place of English in Germany, and notes the contradictory situation that Germans feel the need to speak English with English native speakers despite any difficulties they have with the language. This often results in them going against best 
communicative practice by choosing to communicate in English, as English native speakers are frequently highly proficient in German.

A feeling of being limited by poor English proficiency was expressed among the French workers surveyed in Deneire (2008). There was, in contrast, a greater willingness to fight for the right to use French, as witnessed by a number of legal cases cited where workers sued companies which tried to impose the use of English. For Polish users of English, Kasztalska (2014) expresses similar attitudes, namely that English is an asset to learn, but this has strong consequences for their native language. Many see it that Polish has been weakened by the influence of English (cf. also similar opinions reported for Lithuanian in Ruzaite, 2017).

Bolton and Meierkord (2013) surveyed perceptions of English use in Sweden, and found that, for many, written English is not a productive skill. Swedish is by far the dominant language for migrants to Sweden, and especially in everyday life contexts. English is used as a lingua franca when Swedish proficiency is lacking. For most Swedes, English skills are largely receptive thanks to mass media and social media. However, an important point to note about the English part of the national curriculum in Sweden is that no specific variety is assumed; rather, a communicative competence, as well as a knowledge of how English is used in different contexts, is the focus, which mirrors the framing of ELF (cf. Hult, 2017).

Modiano (2003) notes that Swedish learners of English adopt a mixture of British and American English norms, for spelling in particular but also syntax. Loanwords from English are rife in Swedish, but their spelling is adapted to Swedish spelling norms, for example, mail becomes mejl, with the same pronunciation. Modiano notes that, similar to other learners, Swedes transfer L1 syntactic patterns onto their L2 English, which indicates tendency to promote native linguistic standards on the L2 English. One such example, among many, is the use of preposition phrases after anticipatory it, as in it is common with much snow in winter.

While a move from a native-speaker focus towards a non-nativespeaker one when it comes to norms of English may be desirable, it is more controversial whether the focus should be on non-native-speaker norms wholly. Groom (2012) has seen in her teaching practice that learners and teachers had negative attitudes towards ELF; therefore, she 
surveyed users of English in Europe and asked them about their goals for learning English. She found that there was strong resistance to the idea of learning a European ELF only. However, her informants did not want to speak a pure native variety either, preferring to mix native and non-native features to ensure intelligibility. When played recordings of the same text read by native and non-native speakers, the learners still rated the native version higher and judged them to be more intelligible. An important feature of Groom's survey was that she focused on users of English, and this is the method followed in the survey presented below.

Teachers were surveyed by Young and Walsh (2010), who found a large majority who assumed that one of the native (Inner Circle) varieties was the variety they were going to teach in the future. They were asked about ELF, and thought it was an interesting concept, but that it was not useful for the classroom. It was described in interviews as "ok for ordering drinks on holiday", but not for conducting business (Young \& Walsh, 2010, p. 133). Phillipson (2008) argues that ELF as a concept might come with very negative baggage, for example, being associated too much with the native varieties, or the complete opposite, that ELF is a kind of pidgin English in its most negative sense.

Zeiss (2010) carried out a similar survey to that in Groom (2012). Her informants saw it as an asset to learn English and that it did not devalue their native languages (in contrast to the attitudes from Polish speakers noted above by Kasztalska, 2014). They were tolerant of others speaking English with a non-native accent and non-standard grammar, but were not so tolerant of their own non-native pronunciation and non-standard grammar, preferring to have close to native proficiency themselves (cf. also Jenkins, 2007).

We have seen many different views of English and its status in Europe, and we can reasonably conclude that the status of English is as unclear in Europe as it is in Africa or Asia.

\section{Methodology}

With the above background in mind, it was decided to focus on the following issues when developing the questionnaire part of the study: 
- What are the informants' reported attitudes to English varieties?

- What type of English do the informants report is of most use to them?

- Do the informants report that there is value in learning such a variety as "English as a Lingua Franca"?

- Who do the informants report that they go to for advice about English, native or non-native speakers?

- How appropriate do the informants report that it is to use ELF with native and non-native speakers of English?

Groom's (2012) questionnaire was adapted to go into more detail into the use of ELF, and in particular into the use of ELF with either native or non-native users of English, as the context of its use was of interest but was not developed by Groom. It was also decided to add a test of informants' attitudes to features argued to be characteristic of ELF, but these results will not be reported here. The questionnaire was piloted on a smaller group of students, and this resulted in the wording being changed on questions to do with ELF, since they reported that more explanation was needed for what this term referred to.

All students with a non-English background studying English on netbased courses at a Swedish university were contacted and asked to fill in the questionnaire, which is included in the Appendix. The university is mid-sized and is located in the centre of Sweden. It has around 13,000 students, two-thirds of whom study on net-based courses. The survey was opened from October to December of 2015. The informants were informed about the project, and told they could withdraw from the study at any time. The questionnaire was created through Google Forms, and so anonymity could be guaranteed since it was not possible to determine which individual had given which set of answers.

To complement this survey, and to determine the actual language practices of such students, textchat data from an introductory course to English Linguistics were also analysed to identify their attitudes to the usage of a particular feature of netspeak, the reduced form (White, 2015, 2018). This will be explained in more detail in Sect. 5 .

It was not an aim to achieve equal numbers from different countries in the survey results, as it depends so much on the student intake. In terms of the informants' native languages, 37 of the 60 informants who 
completed the survey $(61.67 \%)$ reported that they were native speakers of Swedish (sometimes bilingually together with a language other than English). Twenty had a different European language only as their native language (33.33\%), and three reported having non-European native languages. Given the difficulty in getting an even sample of speakers of different native languages, no attempt was made to identify any differences in attitudes based on native language.

Let us now turn to the results of the survey, starting with the informants' view of the importance of the English language.

\section{Results from the Questionnaire}

\section{The Importance of English}

The first main set of questions in the survey dealt with how important English was in different parts of the informants' lives: their careers, personal relationships and so on. The results are summarised in Table 3.1 (the percentages refer to the relative frequency within each aspect of life):

An average of $48.67 \%$ considered that English is Vitally important in their lives across all areas, and a further $34.67 \%$ considered it to be Quite important. A total of $96.67 \%$ considered that English was Vitally or Quite important for their Career, and 95\% considered the same for Education. The mean was calculated for these figures—scoring 4 for Vitally important, 3 for Quite important, 2 for Not very important and 1 for Completely unimportant. The means for Career and Education were 3.68 and 3.70, respectively, meaning that the majority of informants chose Vitally important. A very common trend in education in Europe is that more and more courses are offered through English only (as the following article from BBC News from 14 January 2016 attests, http:/www.bbc.com/news/business-35282235), so the informants are acknowledging this fact in ascribing English such a high status. As already mentioned above, education is seen as the domain of English, and in particular of standard English. These results back up the strong linguistic capital still associated with English in a globalised world (Park \& Wee, 2012). 


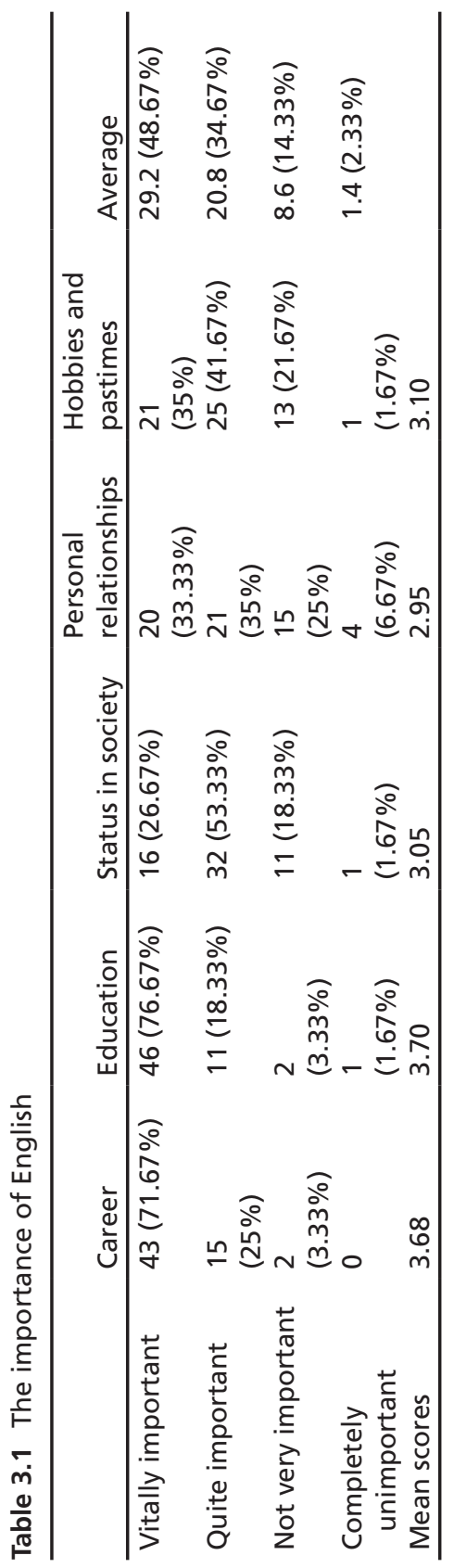


For their Status in society, informants rated English highly, but this stuck out as having more choosing Quite important than Vitally important (32 vs. 16 , or 53.33 vs. $26.67 \%$ ). The mean here was 3.05, showing that it is ranked as Quite important. Knowledge of English is an inherently individual matter, quite possibly strongly linked to individual identity (although this was not investigated), but it seems that knowledge of English is an individual rather than a society-level issue for these students. This does suggest that English does not have such a strong connection to particular societies, indicating that ELF may be more linked to performance in interaction (cf. Saraceni, 2008 and House, 2014).

The results for Hobbies and pastimes, and Personal relationships are the least strong, with close to one-third choosing Not very important or Completely unimportant. The means were 3.10 and 2.95, respectively, showing a similar level to Status in society. Naturally, it depends on individual informants whether English is relevant for relationships and hobbies. An anonymous reviewer questioned why media consumption was not included, but the intention was to capture how much the informants used English, rather than passively consumed it. Maybe the production of media, such as web content, could have been included, but this will have to be the subject of a further study. In a study of extramural English, that is, contact with English outside school time, Sundqvist and Sylvén (2014) report that 10-11-year-olds in Sweden had much contact with English, nearly as much as they had with Swedish in fact, and that those informants who played digital games had a greater motivation to learn and use English. There were still issues with how confident they were to use their English, as the stereotype that Swedes are highly proficient users of English is often not matched by the reality (pp. 13-14). My results do, to some extent, back up Sundqvist and Sylvén's finding about extramural English, with nearly 77\% in my survey reporting that English was Vitally or Quite important for Hobbies and pastimes.

\section{What Standards of English?}

Next, we have questions dealing with standards in English. Informants were asked whether they aimed to be near-native in their proficiency, and 
19 reported that they aimed for native-like proficiency because they would mainly be speaking with native speakers (31.67\%). Thirty-six reported that they also aimed for native-like proficiency, but that would mainly be speaking with other non-native speakers $(60 \%)$. This is a higher result than Zeiss (2010, pp. 102-103) reported, as her informants Agreed or Agreed strongly that they aimed for near-native proficiency at a frequency of $82 \%$ (in my survey, the combined result was $91.67 \%$ ). This demonstrates that the drive for nativeness is still very strong among second-language users of English, despite discussions in academic literature about the suitability of non-native varieties. As alluded to in Zeiss' discussion of the issue, this may have to do with the academic programme of the students. The informants here were students on English courses, and so may have stronger attitudes to, and pre-conceptions about, proficiency and standards (this is something a follow-up interview may have revealed).

When also asked who they turned to for advice about their English, 14 informants answered that they would go to native speakers only $(23.33 \%)$, nine that they would go to other non-native speakers only (15\%), but a majority of $37(61.67 \%)$ reported that they would go to both native and non-native speakers. This does support what is reported in some literature that non-native users often see other proficient non-native users as better role models than native speakers (cf. Zeiss, 2010 and Sung, 2013, 2016). The option of going to a role model such as a highly proficient non-native teacher was not included, but may well be a reason for the strong preference for both native and non-native speaking helpers.

Some general questions were asked about students' attitudes to English as a lingua franca. In the questions, the concept of ELF was presented, that is, it is a reduced variety used for communication between speakers who do not have English as a native language. It must be admitted that it is not ideal to introduce the concept of ELF just in the survey itself, as this may have been the first time the informants had heard of the term. Thus, they could not give a reasoned assessment of the choice of ELF vs native variety. This is a clear limitation of the method chosen. The survey should be administered in conjunction with introducing the concept of ELF in a course environment. 
The first question concerned whether the informants thought ELF should be taught in schools as opposed to a native variety, and the results can be seen in Fig. 3.1:

We see that the majority were negative towards this idea ( 45 , or $75 \%$, chose either Somewhat negative or Completely disagree). This was slightly less than Groom's (2012, p. 52) result, with 80\% there choosing Disagree or Strongly disagree in her survey.

The next question concerned whether informants would prefer to learn ELF rather than a native variety, with the results depicted in Fig. 3.2:

The results were even stronger here, with $82 \%$ negative towards the idea, which was the same result as in Groom (2012, p. 53).

The final question concerned whether the informants would like to be identified as speakers of ELF, and the results can be seen in Fig. 3.3:

A total of $70 \%$ were negative towards this idea, with over $18 \%$ neutral. This is a higher percentage than in Groom (2012, p. 53). For her, 56\% were negative, with $34 \%$ neutral. It is very clear that ELF is still not fully acceptable as an appropriate target for learners. As a supplementary question the author sent by email to the informants, it was asked whether ELF ought to be used as a complement to a native variety of English, and a big majority of respondents were positive to this idea: 50 expressed a

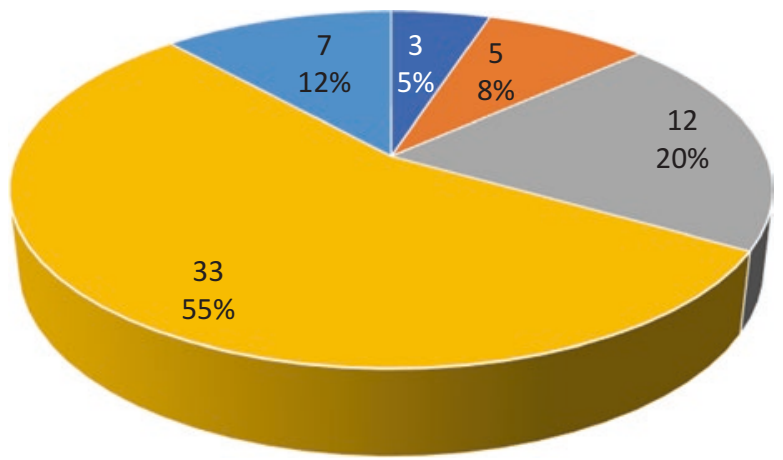

Completely agree Somewhat agree Somewhat negative

Completely disagree Neutral

Fig. 3.1 Should ELF be taught rather than a native variety in schools? 


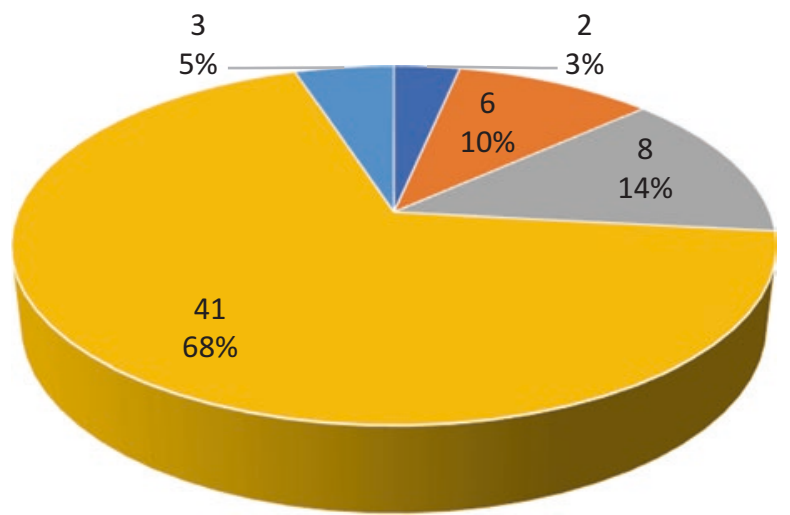

Completely agree Somewhat agree Somewhat negative Completely disagree Neutral

Fig. 3.2 I would prefer to learn ELF rather than a native variety

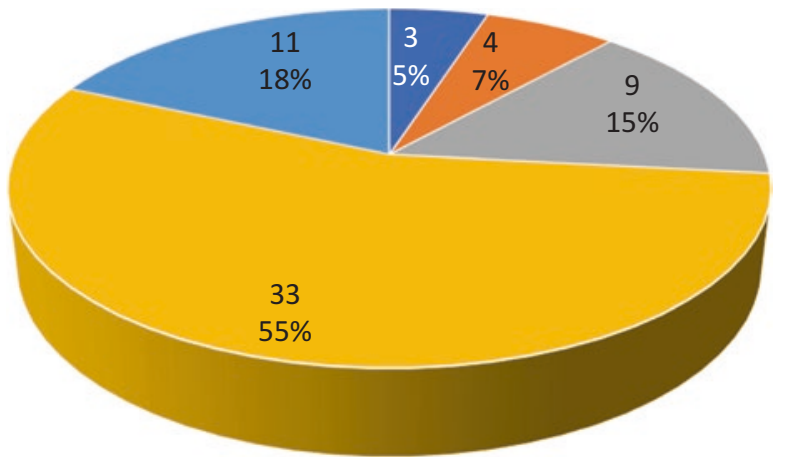

Completely agree Somewhat agree Somewhat negative Completely disagree Neutral

Fig. 3.3 I would like to be identified as a speaker of ELF 
positive attitude, with two against and the rest neutral. Thus, we can surmise that the informants still view ELF as another register of English to be learned alongside a standard (maybe native Inner Circle) English variety, for example. In general, we can conclude that very few are neutral regarding the type of English they want to learn or be identified as. This is to be expected if language is so intrinsically tied up with personal identity.

Next, the appropriateness of using ELF with native and non-native speakers in different situations was investigated (Table 3.2):

For native speakers, the Classroom stood out as the environment where ELF should not be used, with half of informants choosing Not appropriate. The mean was lowest at 1.92 (less than the level of Ok, but would not do so myself). Work also had a very low mean of 2.05. The most appropriate situations were Socially and Online, with means of 2.63 and 2.68, respectively. Other situations were given a mean of 2.60, just under the previous categories. For all situations except in the Classroom, around half of informants indicated it was ok to use ELF, but that they would not do so themselves. Thus, most still have high proficiency demands on themselves, but are more accepting of non-native performance by others (cf. Jenkins, 2007 and Zeiss, 2010). We thus see a contrast between classroom and online domains. What will be the situation when they are combined on a virtual learning site is the main issue in the second part of the analysis in Sect. 5 below.

The results for the use of ELF with non-native speakers are as follows (Table 3.3):

Again, the Classroom is the least appropriate environment for using ELF with a mean of 2.17. Work was also low at 2.32. Although the results were slightly lower, still nearly half indicated it was ok to use ELF, but they would not do so themselves. The remaining means were 2.70 for Socially; 2.80 for Other situations; and 2.85 for Online.

Comparing the two tables in terms of their averages, it was less appropriate to use ELF with a native than a non-native speaker. More informants felt overall that it was Completely appropriate or Appropriate to use ELF with non-native than with native speakers (47.33\% vs. $38.33 \%$ ). The level indicating that it was ok but they would not do so themselves was around $40 \%$ for both categories, confirming Zeiss' result that learners 


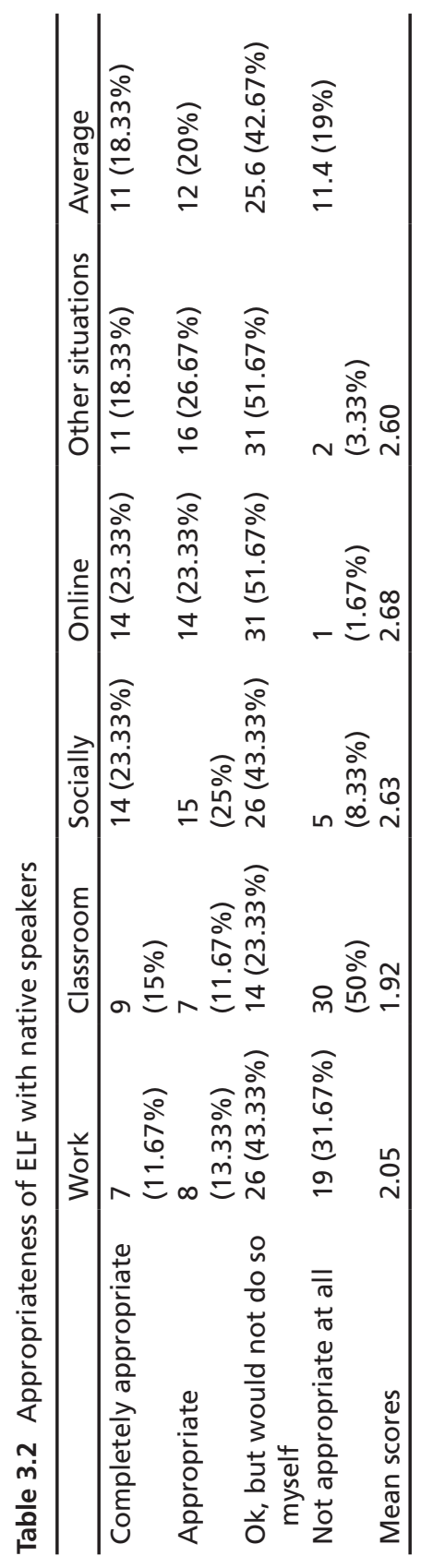




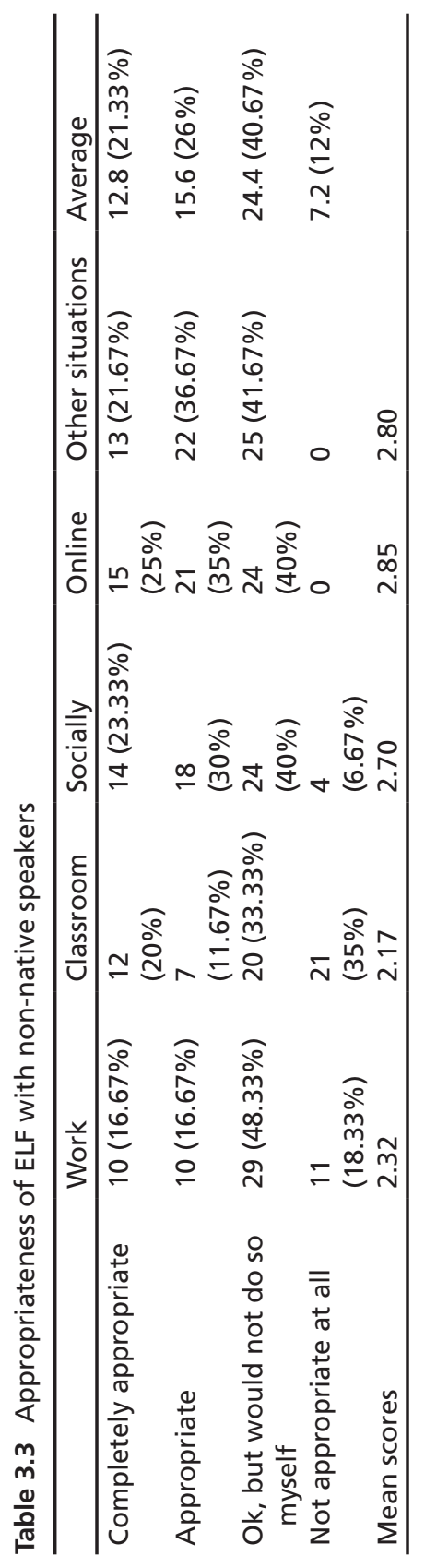


of English tend to be more accepting of non-standard language use with others than with themselves.

The results of this survey suggest that the informants see ELF as a performance variety which they want to learn together with other varieties like native Inner Circle varieties (even though the attitude still prevails that native-speaker varieties are the ones learners aim for). However, their view of education language, in particular, is conservative, with the classroom reported as the major domain where standard language needs to be used, especially with native speakers. We will now look at evidence for informants' actual linguistic practices in virtual learning sites, which comes from textchat data.

\section{$5 \quad$ Norms in Virtual Learning Sites}

The data analysed in this part comes from textchat discussions among students on a net-based MA in English Linguistics. The first course on the programme is our focus, an introduction to core linguistic and sociolinguistic topics. The students divided themselves into pre-seminar groups which then met online without the teachers present. These preseminar discussions dealt with the theoretical and analytical material, and identified questions that the groups wanted to focus on in the seminars with the teachers. These students are particularly interesting to study in that at the time this was the first net-based course they had taken. They also self-reported that they did not have much experience of computermediated communication (CMC) in English. Thus, it can be assumed that they would not have been greatly aware of norms of computermediated communication in English (cf. the more detailed presentation of this data source in White, 2015, and other work).

The specific norm analysed here is the reduced form, where the orthographic forms and/or informality of expressions is reduced. So, instead of writing information, students can write info; and instead of yes, they can write yeah, which creates an informal language (cf. White, 2015, 2018 for a discussion of the different reduction processes in the same dataset). Reduced forms are a stereotypical norm of netspeak, as mentioned in the background. 
Informants' attitudes have already been reported that education is the domain of standard language, although the online domain is different. Still, for students with the background mentioned above, we can hypothesise that they will tend towards standard language norms, and in particular will not produce many of the stereotypical features of netspeak like reduced forms. However, this was manifestly not the case, and there were many examples of reduction. One such typical example is the following:

\section{Extract 1}

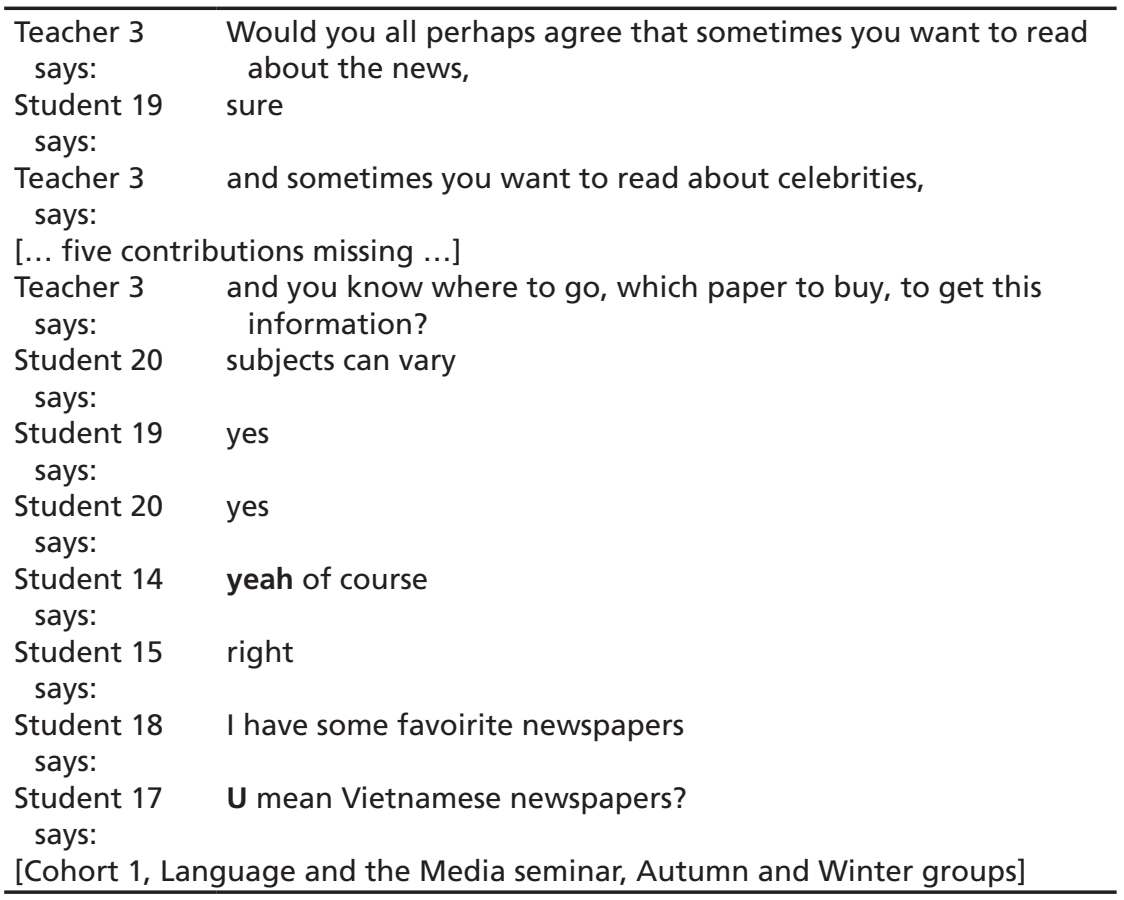

We see illustrated in Extract 1 the varied language used by these students, from the standard yes and you, to the reduced yeab and $u$. This entails that the students have a free view of what sort of language is appropriate to use on virtual learning sites, and the combination of their reported attitudes to language in the classroom and online is in fact confirmed. This sug- 
gests that it is an affordance of virtual learning sites that students can use less formal language than they might otherwise use in face-to-face contexts.

Considering reduced forms specifically now, since the students were inexperienced in CMC, we can further hypothesise that they would follow the norms practised by more experienced users. Specifically, the teachers were all native speakers of English (British, Northern Irish and American), and were experienced CMC users; thus, it would be natural for students to follow their CMC linguistic practices. Indeed, we do see that teachers' norms for reduction are followed by students, as in Extract 2:

\section{Extract 2}

Teacher 1 ok q3 of japanese, Any suggestions?

says:

Student 2 When do we have to hand in Worksheet, Teacher 1?

says:

Student 3 about $r$ and $R$ ?

says:

[... four contributions missing ...]

Student 13 In 3 of japanese. Only 1 example so dificult to find the rule says:

Student 3 I have

says:

Student $9 \quad \mathrm{n}$ appears word- finally in Japannesese

says:

[... two contributions missing ...]

Student 3 because $/ \mathrm{n} /$ is the only final coda in japanese syllable says:

Student 1 because the only consonant at the end of the word is $\mathrm{n}$ in this says: case. the word gomw ended in $\mathrm{m}$ so we

Student 1 need to add $w$ there

says:

Student 2 So, Do we hand in in fronter or to you in April?

says:

Teacher 1 ok Student 13, yes, there is only on example. Student 1 and says: $\quad$ Student 3 have the answer

Student 1 is that right Teacher 1 ?

says:

Student 4 Q3 mostly bases on nasal souds, Student 3

says:

[Cohort 1, Phonology seminar, Spring/Summer groups] 
Teacher 1 uses the reduced form $q$ for question, and this practice is repeated by Student 4 at the end of the extract. However, it is attested in the data more often that the students create their own norms through interaction with one another. The following is an example where a teacher's use of a reduced form is not followed:

\section{Extract 3}

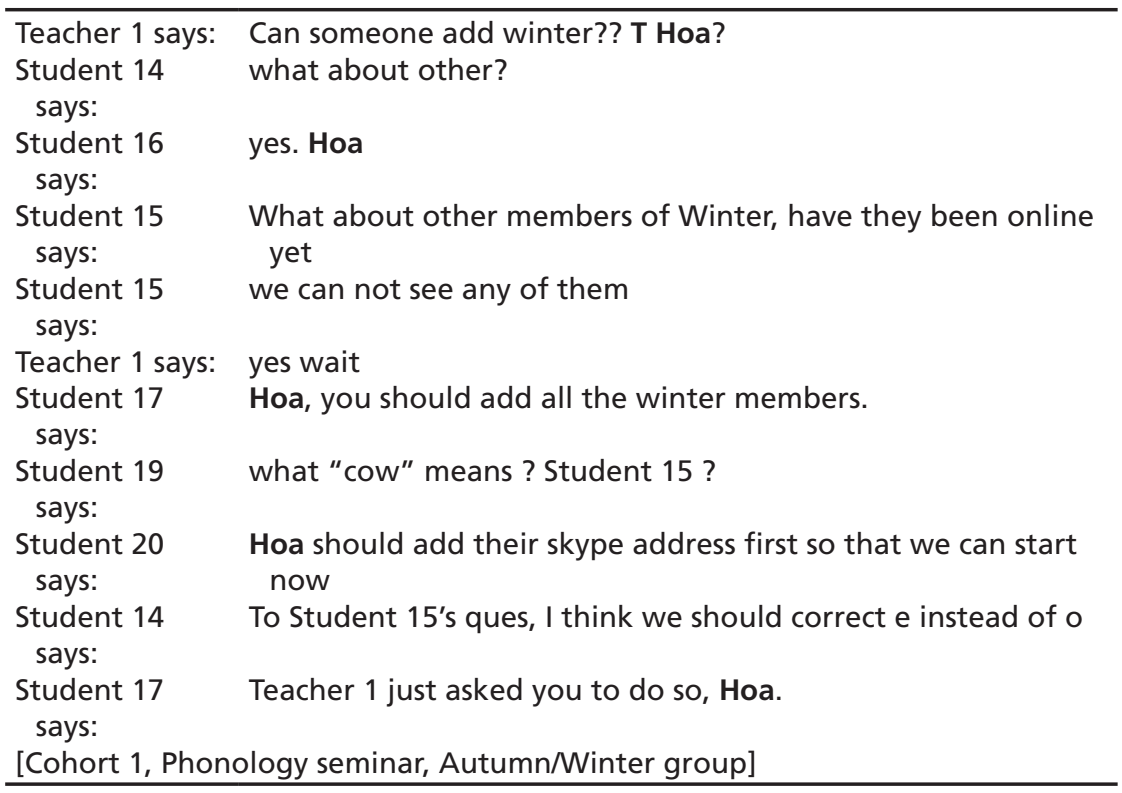

Here, Teacher 2 uses a reduction of Student 14's name, T Hoa, but the other students do not follow this practice, but use the full form. This reflects the more formal nature of communication in learning environments, where naming practices are very important for face. Thus, such practices indicate the more standardised and conventional side of classroom discourse (whether online or not).

We find more extracts where the leaders of the different pre-seminar groups are the ones the others follow in their use of particular reduced forms. For example, we can cite the following: 


\section{Extract 4}

\begin{tabular}{ll}
\hline Student 21 says: & hello \\
Student 21 says: & do u see us online \\
Student 26 says: & hi \\
Student 25 says: & have a good time \\
Student 22 says: & Hi all \\
Student 22 says: & yes! \\
Teacher 2 says: & hello \\
Student 24 says: & hi \\
Student 22 says: & Hi teacher \\
Teacher 2 says: & how are you all? \\
Student 25 says: & fine thanks, and $\mathbf{u} ?$ \\
[Cohort 1, Morphology seminar, Winter group] \\
\hline
\end{tabular}

In this case, the use of $u$ is what concerns us. The group leader, Student 21 , uses the form in the second contribution to the chat, and this is picked up later by Student 25 .

Other students can be "leaders" in the choice of norms, especially those who are experienced in textchat, and are seen by the group as authorities of CMC (cf. the local definition of authenticity practices discussed in the background):

\section{Extract 5}

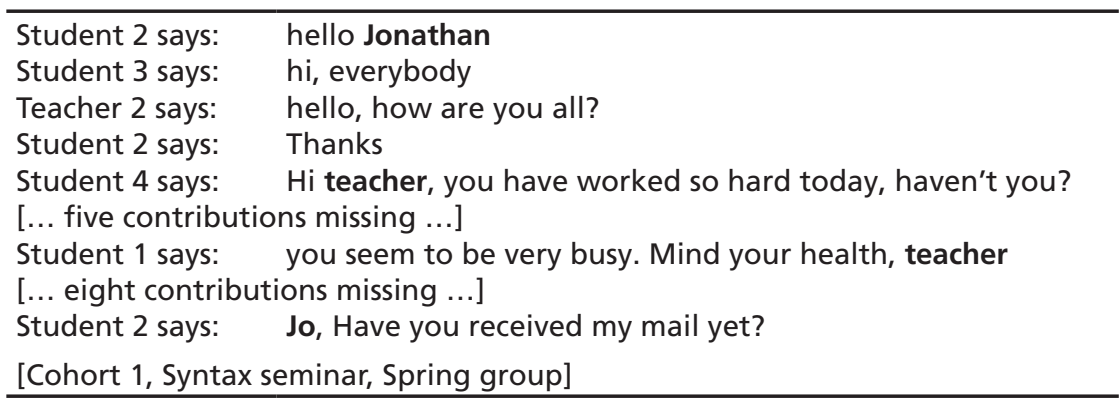

In this extract, we can further consider the naming practices students adopt towards teachers, specifically this author. Student 2 uses my given name, whereas Student 4 and the group leader, Student 1, use the generic title teacher, which is common among Vietnamese students. This practice 
changes for Student 2 when she changes to the reduced form Jo. This gets adopted by Students 5 and 3 later in this chat. Thus, Student 2's practices are seen to be authentic by the others in this pre-seminar group. This is another clear affordance of virtual learning sites, that cultural practices such as naming can be changed, and highly informal forms can be used to an authority figure like a teacher without losing face (cf. also Author, 2016, who discusses this issue).

What we see here from this latter data is that users of English have a more fluid view of norms than is reported in the survey. They can develop their own norms through interaction which are different from those of their native-speaker teachers, and also linguistic practices that go against those of their native cultures. This suggests very strongly that, even though they may believe that native norms are the best to learn, in actual practice they do develop their own norms in interaction with others.

\section{Conclusions}

The survey carried out revealed that second-language users of English are still quite conservative in their attitudes to native varieties, although they do see other second-language users as good role models. ELF is not an alternative, but rather a complement, to native varieties, indicating that the informants see a repertoire of different types of English as the most useful to them. The textchat data indicates, on the other hand, that they are open about using linguistic practices to develop their own communicative norms. Thus, while they may see native Inner Circle varieties as having the highest status, they are clearly willing to develop their own linguistic practices which are different from those of their Inner Circle teachers.

These results support what Zeiss (2010) and Groom (2012) have seen in their surveys, and indicate there is still some way to go for ELF to become acceptable as a full alternative to native varieties. Whether this is a consequence of the hegemony of the native-speaker varieties promoted through teaching materials is not something that can be answered, but certainly the use of ELF is something that needs to be promoted in order for these results to be changed in the future. 
We can clearly conclude that virtual learning sites, despite their being in the Education domain where students reported in the survey that native norms were most appropriate, are environments where local norms can be developed. This is a strong affordance of such sites and is something that instructors can exploit in their teaching. Authenticity is an issue that deserves greater discussion, I believe, and the mis-match between student attitudes and actual practices is of vital importance to discuss for instructors and learners alike.

In terms of future research in this field, accents and their perceptions can be discussed in more detail, and different syntactic features can be investigated, and corpus studies of ELF discourse will help reveal such potential features. Interviews with participants will be a natural followup which can reveal some deeper attitudes and reasons for these attitudes. The comparison of attitudes and actual practices certainly needs to be further investigated. Only one student group was analysed for this work, and it naturally needs to be said that their practices may be down to individual variation, and that other communities of learners may not behave in the same way. Hopefully, authenticity is an area where research and practice in teaching can complement one another in order to create a more balanced perception of English language practices among learners and users, and that interactive practices in virtual learning sites are just as authentic uses of language as more standard written language. 


\section{Appendix: The Questionnaire}

Attitudes to English

Page 1 of 4

\section{Attitudes to English}

"Obligatorisk

1.

What are your native languages? *

2.

What other languages do you speak? *

3.

How important is English for your...? *

Markera endast en oval per rad.

vitally
important
education
ptatus in society
relationships
hobbies and
pastimes

4.

How often do you speak English with the following...? *

Markera endast en oval per rad.

our main language sometimes rarely not applicable

family

friends

teachers

strangers

work colleagues
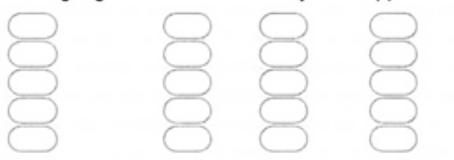

5.

Who do you go to for advice about your English proficiency? *

Markera endast en oval.
native speakers
non-native speakers
both

https://docs.google.com/forms/d/1ajYSkNcAIVAY5_SuluQY9PbaakIPPkyGdhULx... 2016-01-21 


\section{Authenticity of Language Practices in Virtual Learning Sites}

6.

In general, do you aim to develop a near-native speaker level of proficiency in English?*

Markera endast en oval

yes, because I will mainly speak with native speakers

yes, but I will mainly speak with non-native speakers

no

7.

What kinds of English accents do you find easiest to understand? *

Markera endast en oval per rad

\begin{tabular}{|c|c|c|c|}
\hline $\begin{array}{c}\text { No } \\
\text { problem }\end{array}$ & $\begin{array}{l}\text { Generally } \\
\text { fine }\end{array}$ & $\begin{array}{c}\text { Some } \\
\text { problems }\end{array}$ & $\begin{array}{l}\text { Do not } \\
\text { understand } \\
\text { at all }\end{array}$ \\
\hline
\end{tabular}

British

American

Indian/Pakistani/Bangladeshi

Chinese/Japanese/Thai/Vietname

se

Australian/New Zealand

South African

Irish/Scottish/Welsh
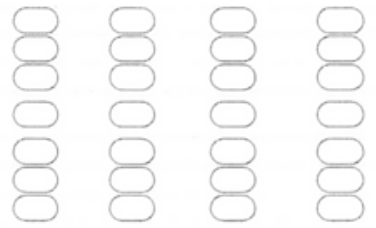

Please describe in your own words

what kind of English you want to use *

9.

A simplified form of English is sometimes used for communication between those who do not have a common first language. This is called English as a Lingua Franca. It often has no verb agreement "she say", and no articles "I

bought book over there". Do you agree or disagree with the following statements about this kind of English?"

Markera endast en oval per rad.

$\begin{gathered}\text { completely } \\ \text { agree }\end{gathered}$
English as a
Lingua Franca
should be taught in
schools rather
than a native
variety of English
I would prefer to
learn English as a
Lingua Franca
instead of a native
variety of English
I would like to be
identified as a
speaker of English
as a Lingua
Franca

https://docs.google.com/forms/d/lajYSkNcAIVAY5_SuluQY9PbaaklPPkyGdhULx... 2016-01-21 
10.

Is it appropriate to speak English as a Lingua Franca with native speakers in the following situations?

Markera endast en oval per rad.

$\begin{gathered}\text { completely appropriate } \\ \text { appropriate }\end{gathered}$
Wor, but I would
not do so
myself
online
other situation

11.

Is it appropriate to speak English as a Lingua Franca with non-native speakers in the following situations?

Markera endast en oval per rad.

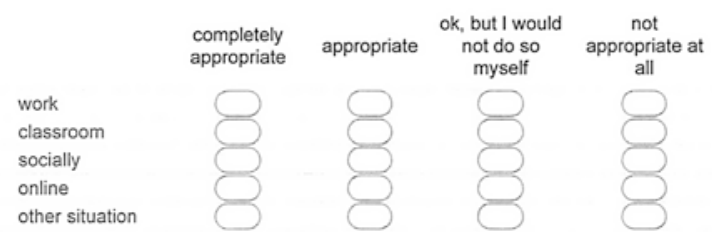

12.

Please rate the folowing sentences which are non-standard English in terms of how good they are *

Markera endast en oval per rad

$\begin{array}{ccccc}\begin{array}{c}\text { completely } \\ \text { ok }\end{array} & \begin{array}{c}\text { fine, but I } \\ \text { would not } \\ \text { use it } \\ \text { myself }\end{array} & \begin{array}{c}\text { completely } \\ \text { bad }\end{array} & \begin{array}{c}\text { do not } \\ \text { understand } \\ \text { the sentence }\end{array}\end{array}$

She look very sad
I saw the book who
I want on the table
I saw the book what
I want on the table
I bought many
books yesterday.
Red one was
expensive
You saw her, isn't
it?
We have got many
advices from our
teacher
We gonna leave
soon
I worked here since
1990
I am born in 1990
We might could
leave soon
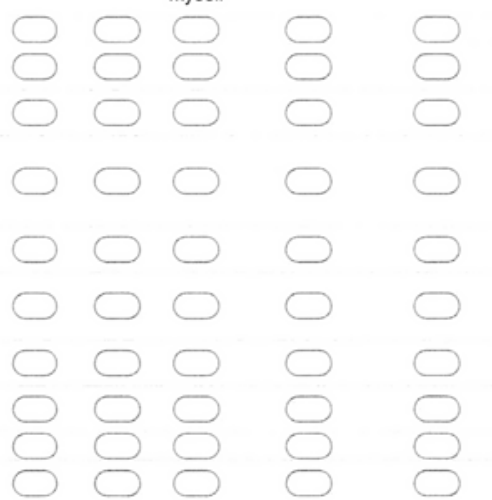

https://docs.google.com/forms/d/lajYSkNcAIVAY5 SuluQY9PbaakIPPkyGdhULx... 2016-01-21 


\section{References}

Alsagoff, L. (2014). Singlish and Hybridity: The Dialogic of Outer-circle Teacher Identities. In R. Rudby \& L. Alsagoff (Eds.), The Global-local Interface and Hybridity (pp. 265-281). Bristol: Multilingual Matters.

Bolton, K., \& Meierkord, C. (2013). English in Contemporary Sweden: Perceptions, Policies, and Narrated Practices. Journal of Sociolinguistics, 17(1), 93-117.

Buendgens-Kosten, J. (2013). Authenticity in CALL: Three Domains of 'Realness'. ReCALL, 25(2), 272-285.

Cogo, A. (2008). English as a Lingua Franca: Form Follows Function. English Today, 24(3), 58-61.

Creese, A., Blackledge, A., \& Takhi, J. T. (2014). The Ideal 'Native Speaker' Teacher: Negotiating Authenticity and Legitimacy in the Language Classroom. The Modern Language Journal, 98(4), 937-951.

Crystal, D. (2001). Language and the Internet. Cambridge, UK: Cambridge University Press.

Deneire, M. (2008). English in the French Workplace: Realism and Anxieties. World Englishes, 27(2), 181-195.

Dörnyei, Z., \& Ushioda, E. (Eds.). (2009). Motivation, Language Identity and the L2 Self. Bristol: Multilingual Matters.

Erling, E. J. (2007). Local Identities, Global Connections: Affinities to English Among Students at the Freie Universität Berlin. World Englishes, 26(2), 111-130.

Groom, C. (2012). Non-native Attitudes Towards Teaching English as a Lingua Franca in Europe. English Today, 28(1), 50-57.

Hilgendorf, S. (2007). English in Germany: Contact, Spread and Attitudes. World Englishes, 26(2), 131-148.

House, J. (2014). English as a Global Lingua Franca: A Threat to Multilingual Communication and Translation? Language Teaching, 47(3), 363-376.

Hult, F. (2017). More than a Lingua France: Functions of English in a Globalised Educational Language Policy. Language, Culture and Curriculum, 30(3), 265-282.

Hung, D., \& Chen, D.-T. V. (2007). Context-process Authenticity in Learning: Implications for Identity Enculturation and Boundary Crossing. Education Technology Research and Development, 55, 147-167.

Jenkins, J. (2002). A Sociolinguistically Based, Empirically Researched Pronunciation Syllabus for English as an International Language. Applied Linguistics, 23(1), 83-103. 
Jenkins, J. (2007). English as a Lingua Franca: Attitude and Identity. Oxford: Oxford University Press.

Kachru, B. B. (1985). Standards, Codification and Sociolinguistic Realism: The

English Language in the Outer Circle. In R. Quirk \& H. Widdowson (Eds.), English in the World: Teaching and Learning the Language and Literatures (pp. 11-30). Cambridge: Cambridge University Press.

Kasztalska, A. (2014). English in Contemporary Poland. World Englishes, 33(2), 242-262.

Li, D. C. S. (2010). When Does an Unconventional form Become an Innovation?

In A. Kirkpatrick (Ed.), The Routledge Handbook on World Englishes (pp. 617-633). Oxford: Routledge.

Lowe, R. J., \& Pinner, R. S. (2016). Finding the Connections Between Nativespeakerism and Authenticity. Applied Linguistics Review, 7(1), 27-52.

McKay, S. (2002). Teaching English as an International Language. Oxford: Oxford University Press.

Modiano, M. (2003). Euro-English: A Swedish Perspective. English Today, 19(2), 35-41.

Modiano, M. (2009). Language Learning in the Multicultural Classroom: English in a European and Global Perspective. Lund: Studentlitteratur.

Mollin, S. (2006). English as a Lingua Franca: A New Variety in the New Expanding Circle? Nordic Journal of English Studies, 5(2), 41-57.

Mollin, S. (2007). New Variety or Learner English? Criteria for Variety Status and the Case of Euro-English. English World-Wide, 28(2), 167-185.

Park, J. S.-Y., \& Wee, L. (2012). Markets of English: Linguistic Capital and Language Policy in a Globalizing World. New York: Routledge.

Pennycook, A. (2007). Global Englishes and Transcultural Flows. New York: Routledge.

Phillipson, R. (2008). Lingua Franca or Lingua Frankensteinia? English in European Integration and Globalisation. World Englishes, 27(2), 250-267.

Phillipson, R. (2013). TESOL Expertise in the Empire of English. TESOL in Context, 22(2), 5-16.

Pinner, R. S. (2014). The Authenticity Continuum: Towards a Definition Incorporating International Voices. English Today, 30(4), 22-27.

Pinner, R. S. (2016). Reconceptualising Authenticity for English as a Global Language. Bristol: Multilingual Matters.

Prodromou, L. (2007). Is ELF a Variety of English? English Today, 23(2), 47-53. Ruzaite, J. (2017). Diversity of Attitudes to English in Non-professional Public Discourse: A Focus on Lithuania. English Today, 33(3), 15-24. 
Saraceni, M. (2008). English as a Lingua Franca: Between Form and Function. English Today, 24(2), 20-26.

Seidlhofer, B. (2004). Research Perspectives on Teaching English as a Lingua Franca. Annual Review of Applied Linguistics, 24, 209-239.

Seidlhofer, B., Breiteneder, A., \& Pitzl, M.-L. (2006). English as a Lingua Franca in Europe: Challenges for Applied Linguistics. Annual Review of Applied Linguistics, 26, 3-34.

Stockwell, G. (2013). Technology and Motivation in English-language Teaching and Learning. In E. Ushioda (Ed.), International Perspectives on Motivation: Language Learning and Professional Challenges (pp. 156-175). New York: Palgrave Macmillan.

Sundqvist, P., \& Sylvén, L. S. (2014). Language-related Computer Use: Focus on Young L2 English Learners in Sweden. ReCALL, 26(1), 3-20.

Sung, C. C. M. (2013). 'I would like to sound like Heidi Klum': What Do Nonnative Speakers Say About Who They Want to Sound Like? English Today, 29(2), 17-21.

Sung, C. C. M. (2016). Does Accent Matter? Investigating the Relationship Between Accent and Identity in English as a Lingua Franca Communication. System, 60, 55-65.

Werry, C. (1996). Lingustic and Interactional Features of Internet Relay Chat. In S. Herring (Ed.), Computer-mediated Communication: Linguistic, Social and Cross-cultural Perspectives (pp. 47-64). Amsterdam: John Benjamins.

White, J. R. (2015). Processes and Variations in Language Economisation. Ampersand, 2, 72-82. https://doi.org/10.1016/j.amper.2015.06.001

White, J. R. (2016). Local Norms in CALL Language Practice. International Journal of Computer-Assisted Language Learning and Technology, 6(1), 40-54. https://doi.org/10.4018/IJCALLT.2016010103

White, J. R. (2017). Exploration of Textual Interactions in CALL Learning Communities: Emerging Research and Opportunities. Hershey, PA: IGI Global. White, J. R. (2018). Individual Variation in Reduction Processes in L2 English Academic Textchat. Ampersand, 5, 18-28. https://doi.org/10.1016/j. amper.2018.03.001

Young, T. J., \& Walsh, S. (2010). Which English? Whose English? An Investigation of 'non-native' Teachers' Beliefs About Target Varieties. Language, Culture and Curriculum, 23(2), 123-137.

Zeiss, N. (2010). English as a European Lingua Franca: Changing Attitudes in an Inter-connected World. Verlag Dr. Müller. 